\author{
Світлана ВАРАВА, \\ orcid.org/0000-0002-0489-625X \\ старший викладач кафедри мовної підготовки № 2 \\ Харківського начіонального університету імені В. Н. Каразіна \\ (Харків, Україна) varava22@gmail.com
}

Свімлана ІВЛЕВА,

orcid.org/0000-0001-5986-7491

старший викладач кафедри мовної та загальногуманітарної підготовки іноземиів Одеського начіонального університету імені I. I. Мечникова (Oдеса, Украӥна) svietlanaivlieva@gmail.com

\title{
ФОРМУВАННЯ МІЖКУЛЬТУРНОЇ КОМПЕТЕНЦІЇ ІНОЗЕМНИХ СТУДЕНТІВ НА ПОЧАТКОВОМУ ЕТАПІ: ДОСВІД І ВИКЛИКИ В УМОВАХ ДИСТАНЦЙНОГО НАВЧАННЯ
}

У статті надано сучасний погляд на формування міжкультурної компетениії іноземних студентів, які отримують вищу освіту у ЗВО Украӥни, під час вивчення украӥнської та російської мови як іноземної. Розглянуто методичну стратегію, прийоми та методи, проблеми комунікаиій, що виникають у студентів-іноземиів на початковому етапі, щ⿻о навчаються нерідною мовою опliпе, використовуючи дистанційну технологію платформи ZOOM.

Обтрунтована необхідність формування міжкультурної компетенції для оволодіння мовою навчання та адаптаиії студентів-іноземиів до нових умов перебування в іншому культурному та іншомовному просторі з метою запобігання культурному шоку. Визначені шляхи подолання труднощчів сприйняття та засвоєння іноземними студентами лексико-граматичних моделей нерідної мови. Наведені методи подолання проблем, які виникають у студентів-іноземців у зв 'язку з розбіжностями між рідною та нерідною мовами, менталітетом, культурними, історичними та іншими особливостями краӥни навчання і рідної краӥни.

Виявлені проблеми, щзо впливають на сприйняття та засвоєння мовленнєвих та граматичних моделей, методи подолання иих труднощів у дистаниійному форматі. Автор акиентує увагу на застосуванні системного, ретельного підходу до підбору та подання відповідного текстового та ілюстративного матеріалу, який викликає зацікавленість до теми, що вивчається, дає можливість збагатити та поглибити знання про культуру країни навчання студента. При изьому звертається увага на використання сучасних інтерактивних технологій навчання, які дають можливість враховувати індивідуальні особливості студентів: волю, інтереси, пам'ять, темперамент, логічні здібності.

Продемонстровано, як під час дистанційного навчання відбувається проведення заняття та контроль виконання самостійної роботи студента.

Надані приклади ефективних моделей формування мовної та мовленнєвої компетенції під час онлайн-занять з вивчення нерідної мови.

Звернено увагу на збільшення навантаження та посилення відповідальності викладачів у роботі дистанџійно. Окреслені переваги та недоліки дистанційного навчання, вимоги до здобувачів вищої освіти.

Ключові слова: мовна компетенція, міжкультурна комунікація, діалог культур, міжкультурна компетенція, дистанційне навчання, дистанційні технології, платформи ZOOM, MOODLE.

Svitlana VARAVA, orcid.org/0000-0002-0489-625X Senior Lecturer at the Language Training Department № 2 V. N. Karazin Kharkiv National University (Kharkiv,Ukraine)varava22@gmail.com

Svitlana IVLIEVA, orcid.org/0000-0001-5986-7491

Senior Lecturer at the Department of Language and General Humanities Training of Foreigners Odesa I. I. Mechnikov National University (Odessa,Ukraine) svietlanaivlieva@gmail.com

\section{FORMATION OF INTERCULTURAL LANGUAGE COMPETENCE OF FOREIGN STUDENTS AT THE INITIAL STAGE: EXPERIENCE AND CHALLENGES IN THE FORMAT OF DISTANCE LEARNING}

The article considers a modern view on the formation of intercultural competence of foreign students who receive higher education in the Ukrainian universities, during the study of Ukrainian and Russian as a foreign language. 
Варава С., Івцєва С. Формування міжкультурної компетенџї іноземних студентів на початковому етапі...

We described the methodical strategy, methods and technique, communication problems that arise in foreign students at the initial stage studying in a non-native language online, using the distance technology by ZOOM platform.

The necessity of formation of intercultural competence for mastering the language of instruction and adaptation of foreign students to new conditions of stay in another cultural and foreign language space, in order to prevent culture shock, is substantiated. Ways to overcome the difficulties of perception and assimilation by foreign students of lexical and grammatical models of a non-native language are identified.

The methods of overcoming the problems that arise in foreign students due to differences between native and nonnative language, mentality, cultural, historical and other features of the country of studies and native country are given.

Problems influencing the perception and mastering of speech and grammar models, methods of overcoming these difficulties in the controlled from distance format are identified.

The author emphasizes the application of a systematic, careful approach to the selection and presentation of relevant textual and illustrative material, which arouses interest in the topic studied, provides an opportunity to enrich and deepen knowledge about the culture of the country of studies. Attention is paid to the use of modern interactive learning technologies, which provide an opportunity to take into account the individual characteristics of students: will, temperament, logical abilities.

It is demonstrated how during distance learning takes place the control of student's independent work.

Attention is paid to increasing the workload and strengthening the responsibility of teachers when working remotely. The advantages and disadvantages of distance learning, requirements for higher education students are outlined.

Key words: language competence, intercultural communication, intercultural competence, distance learning, distance technologies ZOOM, MOODLE platforms.

Постановка проблеми. Здобування іноземними студентами освіти в Україні є однією з важливих характеристик університету світового рівня. Збільшення контингенту іноземних студентів $\epsilon$ актуальним завданням на сучасному етапі розвитку вітчизняної системи освіти (Вдовіна, 2019: 46).

Освіта, як фактор формування особистості, повинна базуватися на принципах, які враховують той факт, що іноземна мова стає повною мірою засобом міжкультурної комунікації, важливим та дієвим інструментом навчального процесу загалом та міжособистісних стосунків викладачів зі студентами-іноземцями зокрема (Вдовіна, 2019: 46).

За допомогою різних видів комунікації стає можливим навчання студентів, що належать до різних культур та світоглядів. Оволодіння нерідною мовою $є$ важливим і необхідним компонентом навчального процесу студентів-іноземців за будь-якою спеціальністю. В умовах єдиного інформаційного простору людства, наявності високо розвинутих інформаційних технологій, що дають можливості спілкування людям різних національностей, культурних традицій та віросповідань, актуальною стає міжкультурна комунікація як засіб порозуміння між націями, міжкультурна компетенція як спосіб здобування якісної освіти.

Студенти 3 різних країн світу виявляють бажання отримати вищу освіту у ЗВО України. Це громадяни азіатських та африканських країн, таких як Китай, Марокко та ін., європейських (Туреччини, Болгарії) та країн СНД. Особливої значущості при цьому набуває формування іншомовної, міжкультурної компетенції як спосіб уникнення непорозумінь на культурному грунті у спілкуванні між іноземцями.

Українські вчені-філологи О. А. Застровський та Л. А. Пасик стверджують, що «міжкультурна комунікація $\epsilon$ взаємодією, обміном, зняттям бар'єрів, взаємністю та солідарністю ... різних культур» (Застровський, Пасик, 2010: 3).

Формування міжкультурної компетенції на початковому етапі навчання іноземних студентів починається із формування складників міжкультурної компетенції - мовної та мовленнєвої компетенції. На особливу увагу заслуговує той факт, що формування відбувається у новому для нашої освіти форматі - дистанційно.

Аналіз досліджень. Дослідженням проблеми формування міжкультурної комунікації та компетенції у викладанні української та російської мови як іноземної фахівці в Україні активно займаються більше трьох останніх десятиліть. Уже розроблено багато фахових з наукової точки зору та впроваджених у практику навчально-методичних комплексів, підручників з російської мови як іноземної та української мови як іноземної, що мають на меті формування міжкультурної компетенції у процесі навчання.

Теоретико-методологічну основу досліджень становлять праці вітчизняних та іноземних учених. Влучним, на наш погляд, $є$ формулювання міжкультурної комунікації, що надане О. А. Застровським та Л. А. Пасик. Це визначення зумовлює необхідність формування міжкультурної компетентності під час навчання за кордоном та вивчення нерідної мови іноземними студентами. Вони стверджують, що міжкультурна комунікація є взаємодією, обміном, зняттям бар'єрів, взаємністю та солідарністю двох різних культур (Застровський, Пасик, 2010: 3).

Важливими принципами, що використовуються у формуванні міжкультурної мовленнєвої особистості у разі вивчення нерідної мови, $\epsilon$ принципи, закладені в теорії діалогу культур. 
Ідея діалогу культур, як відомо, висунута М. М. Бахтіним: «...Ми ставимо чужій культурі нові питання, яких вона сама собі не ставила, ми шукаємо в ній відповіді на ці наші запитання, нові смислові глибини. Без цих питань не можна творчо зрозуміти нічого іншого і чужого...» (Бахтін, 1986). Продовжив цю ідею В. С. Біблер, реалізувавши іiі в освіті, розробивши психологопедагогічну концепцію, принципи і елементи якої можуть бути задіяні у навчанні нерідної мови студентів-іноземців.

Мета статті. Автори поставили перед собою завдання продемонструвати можливість формування міжкультурної компетенції іноземних студентів, що виявляли бажання отримати вищу освіту в ЗВО України в умовах дистанційного навчання, описати недоліки, можливості та перспективи навчання іноземців нерідної мови.

Викладосновногоматеріалу.Формуванняміжкультурної компетенції на початковому етапі здійснюється завдяки мові і мовним засобам, зокрема iii лексико-понятійному арсеналу. Оволодіння нерідною мовою студентами-іноземцями відбувається в декілька етапів. По-перше, оволодіння рівнем мовної правильності. Такий рівень досягають завдяки вивченню правил користування мовою, іiі лексикою, граматичними формами, елементами текстотворення. На цьому етапі студенти набувають вміння будувати речення, нескладні типові тексти і виконувати післятекстові вправи до них.

По-друге, вміння реалізовувати себе у висловленнях відповідно до власного внутрішнього стану; вміння творити і виражати себе засобами мови. На цьому етапі студенти вчаться володіти основними формами усного і писемного спілкування (монолог, діалог, опис, розповідь, міркування). Цей рівень повинен продемонструвати певну виразність мови і комунікативну достатність.

По-третє, продемонструвати рівень насиченості мовою. Мова студента характеризується логічністю, предметністю, точністю, виразністю, образністю, багатством мовних засобів. Студент стає здатним до самостійного викладання письмово та усно текстів, що потребують вміння аналізувати й робити висновки, що дає можливість долучати такого рівня студентів до наукової діяльності.

Мовленнєва компетенція формується системно під час навчання завдяки поступовому введенню відповідних знань з фонетики нерідної мови, граматичних конструкцій, лексичних одиниць та лексичних тем. I на практиці відпрацьовується шляхом аудіювання, виконання післятекстових завдань саме під час заняття та діалогу з викладачем і між собою. Студенти-іноземці за підсумком навчання нерідної мови як іноземної отримують навички, уміння, отримують знання, які формують міжкультурну компетенцію та здатність до сприйняття навчального матеріалу за фаховими дисциплінами.

Кожне заняття з вивчення нерідної мови - це перехрестя культур, це тренування міжкультурної комунікації i, зрештою, відпрацювання та закріплення накопичених мовних навичок та здобутків у навчанні: «Кожне слово відображає інший світ», іншу культуру, інше уявлення про світ, у якому перебуває людина.

Методичні прийоми, які використовуються під час навчання, націлені на активізацію та вдосконалення практичних навичок та умінь студентів у таких сферах мовленнєвої діяльності, як читання, аудіювання (сприйняття та розуміння текстів соціально-культурного, соціально-політичного характеру), мовлення (формування навичок діалогічного й монологічного відповідно до ситуативних моделей комунікації); письмо (формування вмінь та навичок, необхідних для виконання різноманітних письмових завдань у процесі навчального й побутового спілкування) (Чикало, 2019: 31).

Навчальна програма складається з урахуванням особливостей іноземної аудиторії: рідної мови студентів, етнічних та культурних відмінностей, темпераменту, базової мовної підготовки. У виборі навчальногоматеріалувикладачкеруєтьсянеобхідністю якомога простіше ввести студента в нерідну для нього мову, супроводжуючи свій виклад прозорими прикладами, що легко запам'ятовуються. У викладанні широко використовуються презентації, фільми, методи комп'ютерної «симуляції» та моделювання, ділові ігри тощо.

Навчально-методичні матеріали розробляються таким чином, що обов'язково містять відомості про країну навчання, її географічне положення, політичний устрій, відомості про столицю та найбільші міста, відомості про структуру етнічного, релігійного складу населення. При цьому відбувається порівняння рідної й нерідної країни, мови, акцентується увага на схожості й розбіжностях культурних, етнічних, соціальних норм двох країн.

Усвідомлене й глибоке знання про мову або мови з'являється найчастіше у процесі порівняння. Метод порівняння рідної мови студентів 3 мовою навчання - один з ефективних методів, що використовується у викладанні УМІ та РМІ.

Ефективним в аудиторній роботі бачиться застосування евристичних методів, які передбачають включення в процес навчання аналізу надбаних знань, осмислення, образного мислення, фантазування, діалогу з партнером і т.п. 
Варава С., Івцєва С. Формування міжкультурної компетенціі іноземних студентів на початковому етапі...

На початковому етапі здобувачі опановують усталені мовні звороти, що застосовуються у відповідному мовному середовищі. Дуже корисним виявляється повторення цих мовних конструкцій за викладачем хором, відпрацювання парами (діалоги). Згодом, навчившись шляхом аудіювання сприймати на слух нерідну мову і читати та розуміти написане, починається накопичення лексичного матеріалу, мовних кліше, студенти-іноземці навчаються усвідомлювати прочитане, відповідати на питання; у складанні розповіді про свою культуру або нову культуру, з якою вони знайомляться, виокремлювати головне від похідного, навчаються вступати в діалог, дискусію тощо.

Під час занять студентам пропонується, наприклад, текст до прочитання, набір лексем, приклади використання сукупності граматичних конструкцій за загальною лексичною темою тексту. Як допоміжний матеріал пропонуються відповідні презентації, фільми, для контролю засвоєних знань - індивідуальні післятекстові завдання.

Важливо звернути увагу на загальні та більш поширені проблеми, що виникають протягом навчального процесу у студентів-іноземців із різних країн світу. Більшість проблем іноземців під час набування мовної, мовленнєвої та міжкультурної компетенції виникає завдяки приналежності рідної та нерідної мови до різних морфологічних систем (наприклад, аглютинативні - турецька, флективні - російська, українська) і докорінних відмінностей поведінкових моделей у зв'язку 3 розбіжностями культурних, етнічних, релігійних традицій. Такі та інші проблеми вирішуються викладачами за допомогою сталих методів і прийомів викладання нерідної мови. Безсумнівно, що коли студенти під час вивчення фонетико-лексичного мінімуму мають реакцію впізнавання, наприклад, із введенням такої лексики, як тюркізми та слів іншомовного походження. Впізнавання таких прикладів вимови окремих звуків та слів викликає у студентів позитивний емоційний заряд радості впізнавання та впевненості у тому, що вони впораються $з$ таким складним, як їм здається завданням, як оволодіння нерідною мовою.

Великим стимулом до навчання $\epsilon$ виховна робота, яка стала майже неможливою під час карантину та дистанційного навчання.

Виховна та профорієнтаційна робота була до цього часу невід'ємною частиною навчального процесу студентів-іноземців. Викладачі 3ВО проводили тематичні бесіди, просвітницькі лекції, екскурсії до цікавих міст. Саме під час проведення таких заходів у студентів-іноземців відбувалася безпосередньо на практиці міжкультурна комуні- кація. Студенти «вживу» стикалися з іншою культурою, з іншими законами існування, нормами та правилами, що існують в Україні.

Улюбленими заходами студентів-іноземців були екскурсії, лекції та бесіди про родинні стосунки та традиції (весілля, поховання), що дуже різняться в Україні, Марокко, Китаї, Туреччині, про державні символи України. На відповідних заходах розглядаються історичні, культурні та релігійні традиції рідної країни та України («Схожість та розбіжності між арабською та українською культурами», «Святкування Нового року за китайським календарем», «Свята «вишиванки» та «хіджабу» у жіночому одязі», національні свята рідних країн, національні свята новітньої України).

Аналізуючи, порівнюючи та співвідносячи культуру, мову, звичаї, традиції своєї країни, своєї рідної культури зі знаннями, що здобуваються під час навчання в іншій культурі, іншою мовою, в іншому соціумі здобувач освіти швидше опановує, глибше засвоює нову для себе мову, стимулюється та мотивується до навчання.

Здобуті під час навчання знання про культуру, звичаї, систему правил та норм в українському суспільстві дають змогу студенту бути спроможним до міжкультурного спілкування, взаємодіяти 3 представниками культури країни навчання засобами нерідної мови.

Пандемія поставила перед освітянами нові завдання та вимоги, вирішення яких потребувало найшвидших дій.

До об'явлення тотального карантину в Україні та світі дистанційне навчання було впроваджене лише як форма реалізації заочної форми навчання, яка не використовувалась для навчання іноземних студентів. Під час пандемії перехід на дистанційне навчання став єдиним можливим шляхом надання освітніх послуг іноземним громадянам.

Перед викликом опинилися не тільки здобувачі вищої освіти - іноземці, а й викладачі 3ВО, які були вимушені швидко переорієнтуватися та перейти до дистанційного надання освітніх послуг. Процеси трансформації у сучасному суспільстві викликали необхідність спрямувати сучасну освіту до розвитку дистанційного навчання.

Дистанційне навчання на підготовчому відділенні для іноземців ОНУ імені І. І. Мечникова базується переважно на платформі ZOOM. Метою та завданням курсу російської мови як іноземної $\epsilon$ впровадження алгоритму методичної стратегії для ефективного формування уздобувачів вищоїосвіти міжкультурної компетенції на початковому етапі.

Вибір платформи ZOOM для організації навчального процесу зумовлений необхідністю 
швидкого розгортання надання освітніх послуг в умовах карантину, простоті оволодіння платформою викладачами та здобувачами вищої освіти.

Платформа ZOOM значно полегшує організацію взаємодії між викладачем та студентами завдяки таким характеристикам: легкому обміну аудіо- та відеофайлами; встановленню обмеження часу на виконання завдань 3 аудіювання; оперативній організації навчального обговорення завдань; зручній автоматичній системі оцінки виконаних студентом завдань; індивідуальній комунікації між викладачем та студентом (обговорення певних індивідуальних проблем у навчанні чи граматичних тем на форумі); можливості збереження загальної картини успішності та виконаних робіт кожного студента; контролю «відвідуваності», активності студентів, часу їх навчальної діяльності в мережі. Має велике значення підбір навчального матеріалу: структурованість курсу завдяки застосуванню тематичних блоків (окремо винесені в блоки: навчальна програма, рейтингова система оцінювання, граматичний, лексичний, лінгвокраїнознавчий матеріал, питання на іспит/ залік, тести тощо) (Варава, 2015: 122-123).

Нормативне забезпечення дистанційного навчання в університеті не досить розроблене і загалом в Україні потребує вдосконалення та доопрацювання. Разом $з$ лінгвістичною та комунікативною компетенцією викладачі повинні постійно вдосконалювати свою технічну компетенцію (Варава, 2015: 122-123), свій професіоналізм у сфері методики викладання за допомогою нових технологій і у сфері дистанційного навчання, а також оволодіватинеобхіднимизнаннямидля використання мультимедійних інструментів, які знаходяться на нових платформах, MOODLE зокрема.

Оскільки робота в ZOOM орієнтована на формування міжкультурної мовної комунікації під час вивчення нерідної мови, матеріали курсу повинні бути доповнені спеціальним ілюстрованим матеріалом, просвітницькими фільмами, які забезпечать студентам-іноземцям можливість опанувати нерідну мову не тільки в обсязі навчальної програми, а й розширити свій світогляд за допомогою віртуального середовища.

Розглянемо докладніше фрагмент уроку, що відбувається дистанційно.

Текстовий матеріал, практичні завдання, методичнезабезпечення, контрольніпитання поточного та підсумкового контролю студенти отримують зі сторінок сайту відповідно до структури курсу та методичних рекомендацій до окремих елементів.

На початку заняття викладач здійснює презентації про Україну, іiї державну символіку, устрій, визначні міста та національні свята. На цьому етапі здійснюється введення нових слів 3 наступним їх озвучуванням та перекладом на рідну мову студента або на мову-посередник. Ретельне ставлення до вибору слів, їх значення, кількість та правильність промови, а також переклад надалі спрощує самостійну роботу студента у вивченні та засвоєнні студентами нових лексичних одиниць.

Далі після знайомства 3 лексичним матеріалом надається презентація граматичного матеріалу та вправи, за допомогою яких відпрацьовується нова лексика та граматика. Заняття відбувається у форматі «Відеоконференція»здемонстрацієютаблиць, схем мовлення, супроводжується коментарями рідною мовою студента або мовою-посередником.

Навчальний матеріал подається у динаміці 3 використанням слухового та зорового каналів сприйняття інформації (Варава, 2015: 122-123).

Наступний етап - самостійна робота студента, що містить читання тексту з метою закріплення лексичного та граматичного матеріалів, виконання післятекстових завдань. Особливо важливим здається чітке формулювання завдань, які надаються рідною мовою студента та мовою-посередником для полегшення відпрацювання та засвоєння навчального матеріалу самостійно.

Виконані практичні завдання, що демонструють ступінь оволодіння навчальним матеріалом, студенти у будь-який спосіб (за домовленістю 3 викладачем: Skype, Viber, E-mail) надсилають на перевірку. Викладач таким самим чином повертає перевірене виконане завдання студентам. У разі необхідності викладач супроводжує виконане завдання коментарями.

Висновки. Досвід нашої роботи щодо формування міжкультурної компетенції іноземних студентів на початковому етапі під час опанування нерідної мови дозволяє зробити такі висновки.

Прийняття нерідної мови відбувається із прийняттям іншої культури, «оскільки культурні моделі, звичаї, спосіб життя виражаються мовними засобами й мова виступає як носій і передавач культури» (Чикало, 2019: 1).

Основою для «формування міжкультурної свідомості є визнання як схожих, так і відмінних рис різних національних культур. Культура $\epsilon$ невідривною частиною взаємодії між мовою й думкою. Культурні моделі, звичаї, спосіб життя, міжкультурний світогляд відображаються в мові» (Чикало, 2019: 1).

У порівнянні мов та культур завдяки реакції впізнавання, відштовхуючись від своєї рідної мови, відбувається міжкультурна комунікація та набувається міжкультурна компетенція. Такій 
підхід викликає інтерес та задоволення, мотивує студентів-іноземців до подальшого заглиблення у навчальний матеріал і викликає інтерес до культури, звичаїв, традицій країни навчання. У процесі обговоренняпроблем,обмінуідеями йміркуванням щодо ціннісних категорій і поведінкових моделей, притаманних іншим народам, студенти-іноземці навчаються розуміти й толерантно приймати їх.

На початковому етапі здобування вищої освіти у ЗВО України саме на викладачів мови насамперед покладається відповідальність за досягнення такого рівня викладання, на якому культурологічні знання служать допомогою у засвоєнні мови та у підсумку отримання високого рівня фахової освіти.

Після проміжку часу у рік постає завдання використання більш технологічних платформ дистанційної освіти на кшталт Moodle, BigBlueButton та інш., які дають більше можливостей для навчання, використовуючи засоби контролю засвоєння навчального матеріалу протягом заняття за допомогою вбудованих у дистанційні платформи блоків поточної перевірки вправ, мультимедійної інтерпретації навчального матеріалу та інші можливості дистанційних технологій.
Виклики сучасності вимагають від викладачів постійного удосконалення своєї компетенції не тільки у сфері свого предмета, а й удосконалення оволодіння сучасними інформаційними технологіями дистанційної освіти. У зв'язку з тим, що під час заняття молоді люди перебувають у свої домівках для утримання їхньої уваги викладач повинен використовувати всю свою майстерність під час заняття, що збільшує фізичне та емоціональне навантаження викладача.

Останнім часом перед освітянами постає проблема стимулювання мотивації здобувачів вищої освіти до навчання, особливо в онлайн-форматі. Це вимагає переформатування навчальних курсів, використання особливого способу подачі навчального матеріалу, використовуючи вищезгадані засоби онлайн-технологій, організацію студентів у групи на форумах задля спілкування та обміну отриманими знаннями. На нашу думку, корисно використовувати перевірку домашніх завдань студентів один одним, що буде стимулювати навчання (Коллір, 2012). Особливо це важливо у гуманітарній сфері, і зокрема у формуванні міжкультурної компетенції.

\section{СПИСОК ВИКОРИСТАНИХ ДЖЕРЕЛ}

1. Азарх К. С. Современные технологии в развитии коммуникативной компетенции иностранных студентов : материалы межд. наук.-практ. конф. Проблеми викладання російської наукової лексики студентам-іноземиям. Харків : НФаУ, 2017. С. 93-100.

2. Азимов Э. Г. Информационно-коммуникационные технологии в обучении РКИ: состояние и перспективы. Русский язык за рубежом. 2011. № 6. С. 45-55.

3. Бахтин М. Естетика словесного творчества. 2-е изд. Москва : Искусство, 1986. 444 с.

4. Бовтенко М. А. Компьютерная лингводидактика : учебное пособие. Москва : Флинта: Наука, 2005. 216 с.

5. Варава С. В. Формирование профессионально ориентированной лингвистической компетенции в русском языке у иностранных студентов инженерных специальностей на начальном этапе с использованием технологий дистанционного обучения. Русский язык и литература в пространстве мировой культуры : материалы XIII Конгресса, МАПРЯЛ в 15 т., Т. 10, 2015. С. 194-199.

6. Вдовіна О. О. Особливості формування комунікативної компетенції іноземних студентів. Херсон. Молодий вчений, 2019. № 5.1 (69.1). С. 47-50.

7. Застровський О. А., Пасик Л. А. Поняття міжкультурної комунікації та порівняльна характеристика німецької та української культур (на матеріалі німецької мови). 10 c. URL: http://esnuir.eenu.edu.ua/handle/123456789/1634, 2010 (дата звернення: 01.03.2020).

8. Камишова Н. В. Методичні стратегії формування міжкультурної комунікативної компетенції школярів на уроках іноземної мови. Одеса. Мова, 2018. № 30. С. 106-111.

9. Манакін В. М. Мова і міжкультурна комунікація : навчальний посібник. Київ : ВЦ «Академія», 2012. 288 с.

10. Чикало I. Українська мова для іноземних студентів. Країнознавство : навчально-методичний посібник для іноземних студентів підготовчого відділення. Львів : НМУ ім. Данила Галицького, 2019. 30 с.

11. Daphne Koller TED Global 2012: WHAT WE'RE LEARNING FROM ONLINE EDUCATION. 2012. URL: https://www.ted.com/talks/daphne_koller_what_we_re_learning_from_online_education/transcript\#t-564.

\section{REFERENCES}

1. Azarh K. S. Modern technologies in the development of communicative competence of foreign student's competence [Sovremennie tehnologii v razvitii kommunikativnoj kompetentsii inostrannih studentov]. Proceedings of the international scientific-practical conference. Problems of teaching Russian scientific vocabulary to foreign students. Kharkov: NFaU, 2017. Pp. 93-100 [in Russian].

2. Azimov E. G. Informacionno-kommunikacionnye technologiyi v obucheniji RKI [sostoyanije i perspektivi]. Rysskij Yazik za rubezgom, 2011. No. 6. Pp. 45-55 [in Russian].

3. Bahtin M. M. Aesthetics of verbal creativity [Estetika slovesnogo tvorchestva], 2nd edit. Moscow: Iskusstvo, 1986. 444 p. [in Russian]. 
4. Bovtenko M. A. Kompjuternaya lingvodidaktika [uchebnoye posobiye]. Moskva: Flinta: Nauka, 2005. 216 p. [in Russian].

5. Varava S. V. Formation of professionally oriented linguistic competence in Russian language for foreign Engineering students at the initial stage of training using distance learning technologies. Russian language and literature in the space of world culture [Formirovaniye proffessional'no orientirovannoy lingvisticheskoy kompetentsii v russkom yazike u inostrannih studentov ingenernih spetsial'nostey na nachalnom etape s ispol'zovaniyem tehnologiy distantsionnogo obucheniya. Russkiy yazuk i litratura v prostranstve mirovoy kul'turi]: materials of the XXI Congress of IATRLL, in 15 vol., V. 10, Collection: IATRLL, 2015. Pp. 194-199 [in Russian].

6. Vdovina N. V. Features of formation of communicative competence of foreign students [Osoblivosti formuvanya kommunikativnoyi kompetentsiyi inozemnih studentiv], Herson. "Young Scientist", 2019. No. 5.1 (69.1) May. Pp. 47-50.

7. Zastrovsksy O. A., Pasyk L. A. The concept of the intercultural communication and a comparative characteristic of the cultural differences in Germany and Ukraine [Ponyattya mizhkult'urnoyi komunikatsiy ta porivnyal'na kharakteristika nimetskoyi ta ukrayins'koyi kul'tury (na materiali nimet'skoyi movi)], 2010. Retrieved from: http://esnuir.eenu.edu.ua/handle/123456789/1634 [in Ukrainian].

8. Kamishova N. V. Methodological strategies of intercultural communicative competence formation of schoolchildren at the foreign language lessons [Metodichni strategiy formuvannya mizhul'turnayi komunikativnoyi kompetentsyi shkolyariv na urokah inozemnoyi movi], Odessa. Mova, 2018. No. 30, pp. 106-111.

9. Manakin V. M. Language and intercultural communication: manual [Mova i mizhkult'urna komunikatsiya: navchal'niy posibnyk], Kyiv: Publsh. Cent. “Academy”, 2012. 288 p.

10. Chikalo I. Ukrainian language for foreign students. Local lore: educational and methodical manual for foreign students of preparatory department [Ukrayins'ka mova dlya inozemnih studentiv. Krayeznavstvo: navchal'niy posibnik dlya inozemnih studentiv pidgotovchogo viddilennya], L'viv: Danila Galbts'kiy NMU. 2019. 30 p.

11. Daphne Koller: TED Global 2012: WHAT WE'RE LEARNING FROM ONLINE EDUCATION. URL: https://www. ted.com/talks/daphne_koller_what_we_re_learning_from_online_education/transcript\#t-564 [in English]. 